\title{
Laser surface treatment of plasma-sprayed yttria-stabilized zirconia
}

\section{coatings}

\author{
M.A. Pinto*, W.R. Osório*, C.R.P. Lima*, A. García* and M.C.F. Ierardi*
}

\begin{abstract}
A continuous wave $\mathrm{CO}_{2}$ laser with a defocused beam has been employed to seal the surface layer of plasma-sprayed of $8 \mathrm{wt}$. \% yttria-stabilised zirconia coatings on AISI 1045 steel substrate. The effect of laser remelting on microstructure and corrosion resistance of plasma-sprayed layer was investigated. The microstructure of the sealed layer presented a cellular structure which grows perpendicular to the surface. The micrographs have shown small cracks and absence of porosity. The corrosion resistance was analysed by the EIS and polarisation tests by using a $3 \% \mathrm{NaCl}$ solution. Laser sealing improved the corrosion resistance of the coating and increased the microhardness.
\end{abstract}

Keywords Laser surface treatment. Yttria-stabilised zirconia. Plasma-sprayed. Corrosion resistance.

\section{Tratamiento superficial por láser de recubrimientos por proyección por plasma de $\mathrm{ZrO}_{2} 8 \% \mathrm{Y}_{2} \mathrm{O}_{3}$}

\begin{abstract}
Resumen
Un equipo láser continuo de $\mathrm{CO}_{2}$, con potencia nominal de $1 \mathrm{~kW}$, se utilizó para sellar la superficie revestida con $\mathrm{ZrO}_{2} 8 \% \mathrm{Y}_{2} \mathrm{O}_{3}$ por proyección por plasma sobre un substrato de acero AISI 1045. Se investigaron los efectos del tratamiento de fusión con láser sobre la microestrutura y la resistencia a la corrosión del recubrimiento. La resistencia a la corrosión se analizó por medidas electroquímicas en una solución de $\mathrm{NaCl}$ al 3 \%. Las micrografias mostraron que la superficie del revestimiento presentó varias grietas pequeñas, sin embargo, no fueron observados poros. La microestructura de la capa sellada presentó una estructura en forma de columnas con crecimiento perpendicular a la superficie libre. El sellado a láser mejora la resistencia a la corrosión de los recubrimientos y aumenta la microdureza.
\end{abstract}

Palabras clave Tratamiento superficial por láser. Zirconia estabilizada con ítrio. Proyección por plasma. Resistencia a la corrosión.

\section{INTRODUCTION}

Zirconia ceramics present a combination of high chemical stability, high wear resistance, high toughness, low thermal conductivity, that make this group of materials particularly attractive for applications in harsh environments under severe loading ${ }^{[1-6]}$.

Plasma spray process is widely used in the application of zirconia ceramics coatings. However, these coatings typically contain porosity that permit contaminants to penetrate through the coating attacking the substrate. In addition, porosity and cracks can lead to degradation, destabilisation, spalling and loss of thermal insulation and corrosion protection of the plasmasprayed coatings ${ }^{[7-14]}$.

Laser surface melting is a promising process for improving the performance of the plasma-sprayed coatings by reducing porosities, densifying the coating, reducing surface roughness and improving its protective efficiency ${ }^{[15-18]}$. Fine microstructures, resulting from rapid cooling from the melt, together with smooth and shiny layers are characteristic features of the laser sealing ${ }^{[14]}$. The plasma-sprayed zirconia coatings sealed by laser have been the subject of several investigations ${ }^{[7-10}$ and $\left.12-27\right]$. These studies have shown that the sealed coatings present a better performance as to cavitational erosion resistance ${ }^{[25]}$,

(*) Department of Materials Engineering, State University of Campinas, UNICAMP, P.O. Box 6122, 13083-970 - Campinas, SP, Brazil. 
surface spalling when they were subjected to a high heat flux environment ${ }^{[26]}$, and lifetime ${ }^{[27]}$ compared with those as-sprayed coatings.

The purpose of this study is to investigate the influence of laser sealing process on hardness and corrosion resistance of surface coatings of $\mathrm{ZrO}_{2}$ 8 wt. $\% \mathrm{Y}_{2} \mathrm{O}_{3}$ produced by plasma spray.

\section{MATERIALS AND EXPERIMENTAL PROCEDURE}

Zirconia coatings were prepared by atmospheric plasma spraying of $8 \mathrm{wt}$. \% yttria-stabilised zirconia powder on an AISI 1045 steel substrate $(65 \times 12 \times$ $6 \mathrm{~mm}^{3}$ ) by using a plasma gun 3MBII SULZER METCO. The samples were first grit blasted with alumina powder. No bond layer was applied on the substrate. The thickness of the coating was about $200 \mu \mathrm{m}$.

A $1 \mathrm{~kW}$ continuous wave $\mathrm{CO}_{2}$ laser with $\mathrm{TEM}_{00}$ defocused beam was used to seal the surface layer of the plasma-sprayed coating. Argon was used as a protective gas. In order to cover completely the surface of the coating, the samples were subjected to multiple scans, with an overlap of $20 \%$ between consecutive tracks, always in the same direction. The plasma-spraying and laser sealing conditions are given in table I.

The coatings microstructures were characterised by optical microscopy, scanning electron microscopy and X-ray diffraction. Microhardness measurements were carried out on the transverse section with a load of $100 \mathrm{gf}$ for both as-sprayed and as-sealed layer conditions. Roughness measurements "Ra" were carried out using a SJ-201 MITUTOYO Surface Roughness Tester.

The corrosion behaviour of the coatings was analysed under aggressive $3 \% \mathrm{NaCl}$ solutions at room temperature. The electrochemical impedance

Table I. Plasma spraying and laser sealing parameters

Tabla I. Parámetros de la proyección por plasma y sellado a láser

\begin{tabular}{|c|c|c|c|}
\hline \multicolumn{2}{|l|}{$\begin{array}{c}\text { Plasma spraying } \\
\text { Parameters }\end{array}$} & \multicolumn{2}{|l|}{$\begin{array}{l}\text { Laser sealing } \\
\text { Parameters }\end{array}$} \\
\hline Voltage (V) & 70 & Power (kW) & $0.8-1.0$ \\
\hline Current $(A)$ & 450 & Beam diameter (mm) & $3.5-5.0$ \\
\hline Arc gas pri. - $\operatorname{Ar}(/ / \mathrm{min})$ & 80 & Scanning speed $(\mathrm{mm} / \mathrm{s})$ & $33.3-300$ \\
\hline Arc gas sec. $-\mathrm{H}_{2}(1 / \mathrm{min})$ & 15 & Power density $\left(\mathrm{W} / \mathrm{mm}^{2}\right)$ & $40.7-103.9$ \\
\hline Carrier gas - $\operatorname{Ar}(1 / \mathrm{min})$ & 30 & & \\
\hline Spray distance $(\mathrm{mm})$ & 120 & & \\
\hline
\end{tabular}

Rev. Metal. Madrid Vol. Extr. (2005) 154-159 spectroscopy (EIS) and the polarisation tests were carried out using a Potentiostat/Galvanoplast Model 273A coupled to a SOLARTRON 1250 Frequency Response Analyser, a glass corrosion cell kit with the working electrodes, a plate platinum counter-electrode and saturated calomel reference electrode (SCE). The polarisation tests were conducted in a scan rate of $0.2 \mathrm{mVs}^{-1}$ from -250 $\mathrm{mV} / \mathrm{SCE}$ to $+250 \mathrm{mV} / \mathrm{SCE}$ in a open-circuit potential.

\section{RESULTS AND DISCUSSION}

The coatings produced by plasma spraying presented a thickness of about $200 \mu \mathrm{m}$. Figure 1 shows a top view (a) and the transverse section (b) of the as-sprayed coating which exhibited high porosity, approximately $10 \%$ in area, as well as vertical and horizontal microcracks. The surface roughness of the coatings was about $\mathrm{Ra}=10 \mu \mathrm{m}$ and the average microhardness about $900 \mathrm{HV}$.
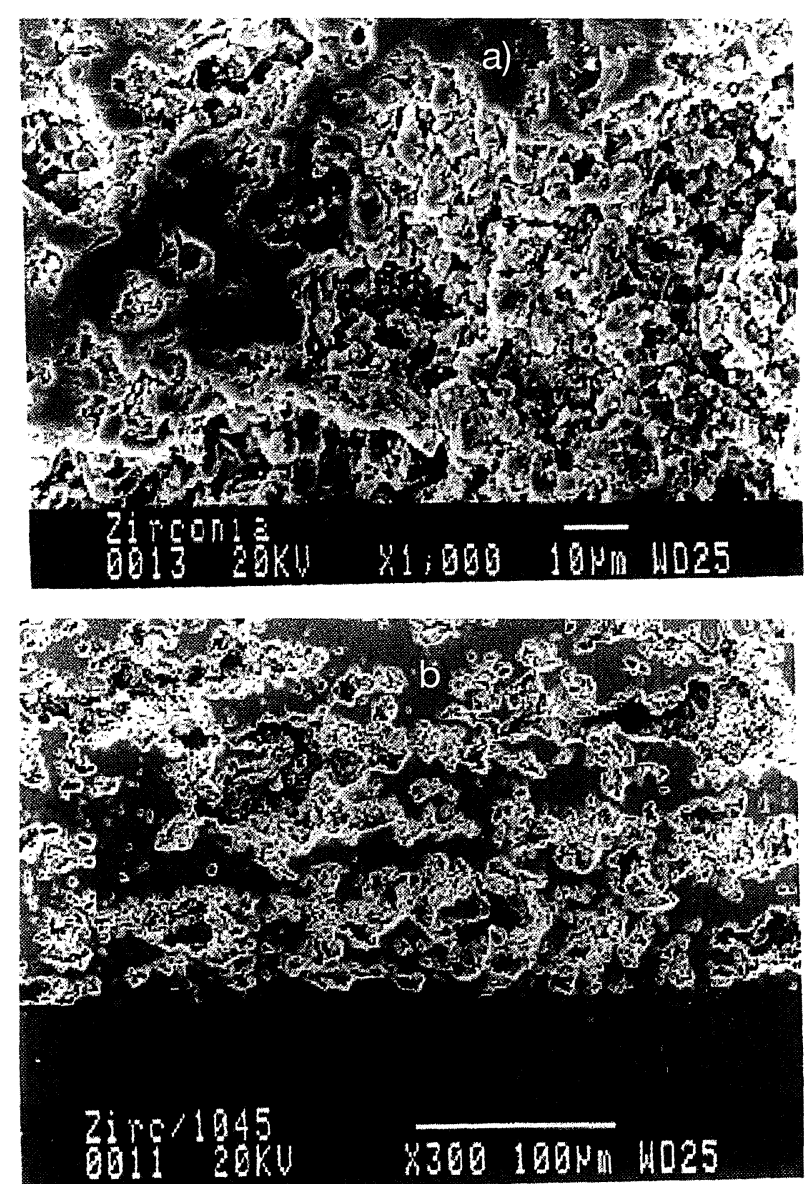

Figure 1. Typical top view of the as-sprayed coating (a) and transverse section (b).

Figura 1. Aspecto de la superficie (a) y de la sección transversal (b) de la capa de $\mathrm{ZrO}_{2} 8 w t$. $\% \mathrm{Y}_{2} \mathrm{O}_{3}$ depositada por proyección por plasma. 
This value is about $38 \%$ higher than that reported for Mohammed-Jasim et al. ${ }^{[13]}$ for the same coating composition.

The diffraction patterns for both starting powder and the as-sprayed coating are shown in figure 2 and present mainly cubic (c) and tetragonal $(\mathrm{t})$ phases. The monoclinic phase which is present in the starting powder has also been detected in the as-sprayed layer.

To produce the sealed coatings several experiments were carried out, under various combinations of the laser operating parameters (Table I), in order to determine the best conditions for laser sealing. The tests were necessary since available data in the literature are still incomplete and even contradictory. The experiments have shown that the depth of the sealed layer increases with increasing power and with decreasing scan speed. Numerous depressions, attributed to gas evolution, were observed on the sealed surface. The average size and the amount of depressions decrease with increasing scan speed, but increase with increasing power. Similar observations have been reported in the literature ${ }^{[14}$ and 28]

From the tests, three coatings, namely S1, S2 and S3, presented the best results in terms of porosity, cracks, roughness and depth sealed. They were produced by using the following parameters: Power: 1000W, Laser beam diameter: $5 \mathrm{~mm}$, Scan speed: S1: $200 \mathrm{~mm} / \mathrm{s}, \mathrm{S} 2: 300 \mathrm{~mm} / \mathrm{s}, \mathrm{S} 3: 350 \mathrm{~mm} / \mathrm{s}$. The diffraction patterns for these coatings are shown in figure 3. All the coatings have microstructures consisting of: cubic (c), tetragonal $(\mathrm{t})$ and non-transformable tetragonal $\left(\mathrm{t}^{\prime}\right)$ phases.

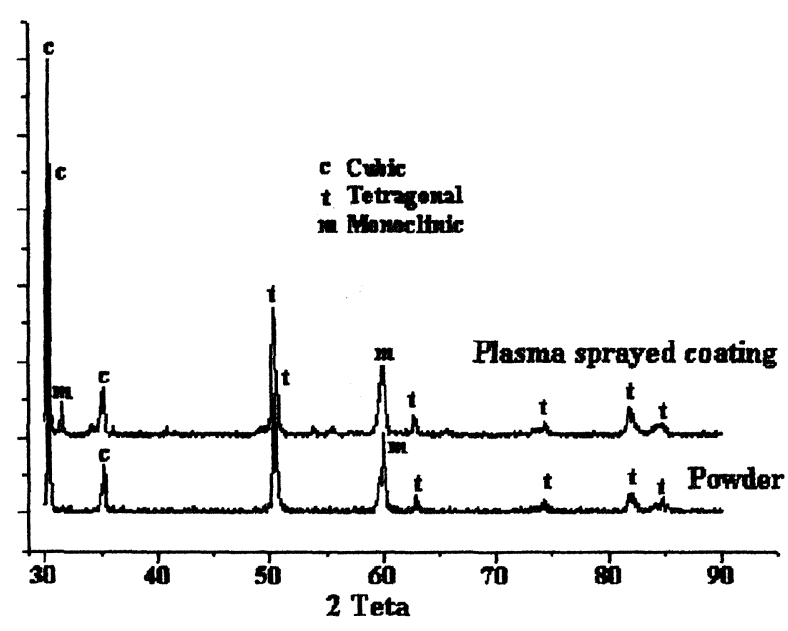

Figure 2. XRD patterns for starting powder and as-prayed layer.

Figura 2. Difractogramas de polvo y de la capa depositada por proyección por plasma.

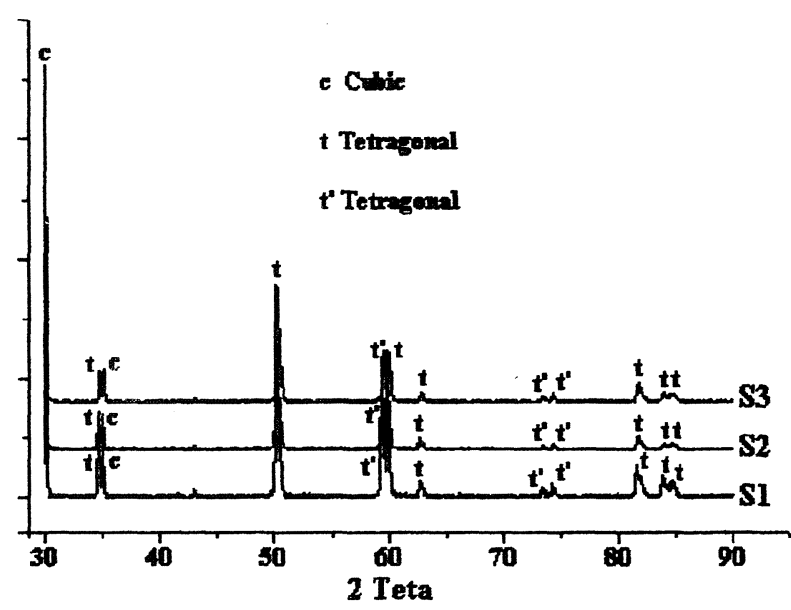

Figure 3. XRD patterns for $\mathrm{S} 1, \mathrm{~S} 2$ and $\mathrm{S} 3$ coatings.

Figura 3. Difratogramas de las capas S1, S2 y S3.

No monoclinic phase was detected. The rapid cooling rate have induced the production of nontransformable tetragonal t' phase during solidification.

The typical micrographs of S1, S2 and S3 coatings are shown in figure 4 . It can be seen that, the coatings presented a cellular structure. The cell size decreased with increased scan speed. The structure of the S3 coating was the same of S2 coating but with a higher amount of cracks. The S2 coating presented the best characteristics when compared with S1 and S3 coatings.

The analysis of the S2 coating has shown a dense resolidified layer (absence of porosity) with a homogeneous fine cellular structure. The sealed surface was smooth, shiny and segmented (network of cracks). The depth of the sealed layer was about $95 \mu \mathrm{m}$ and the surface roughness was about $\mathrm{Ra}=$ $3.6 \mu \mathrm{m}$. The microhardness, measured on the transverse section of the S2 coating, was about $1700 \mathrm{HV}$ which is significantly higher than that observed at the as-sprayed coating condition (900 $\mathrm{HV}$ ). The microstructure of the transverse section of the sealed layer was revealed by fracturing the coating (Fig. 5). It consists of a cellular structure that grows perpendicularly to the free surface. The dendritic structure, as described by Shied and $\mathrm{Wu}^{[29]}$, was not detected in the present experimental investigation.

A comparative study of corrosion behaviour of the as-sprayed and as-sealed coatings is shown in figure 6. As expected, the corrosion behaviour of these coatings is strongly dependent on the treatment conditions. For all coatings experimentally examined, both types of corrosion 


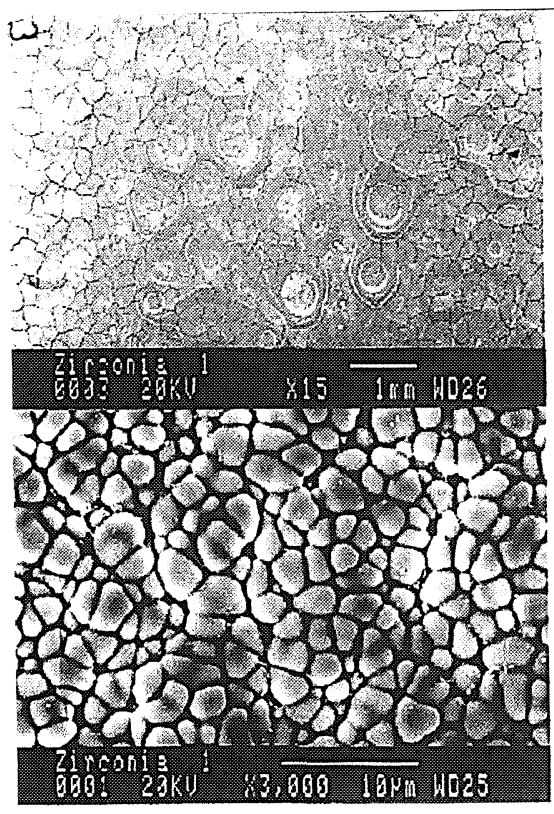

S1
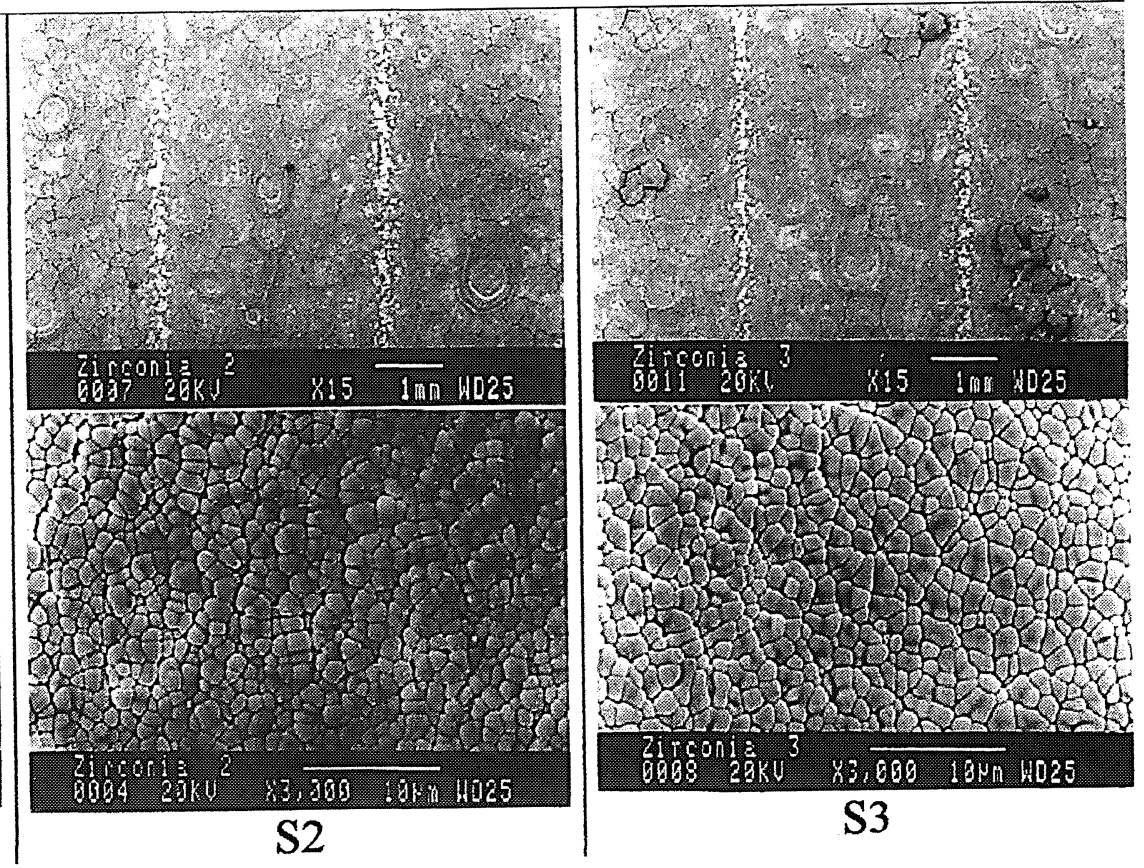

S3

Figure 4. Typical SEM micrographs of the S1 (a), S2 (b) and S3 (c) coatings.

Figura 4. Aspecto de las micrografias MEB de las capas S1 (a), S2 (b) y S3 (c).

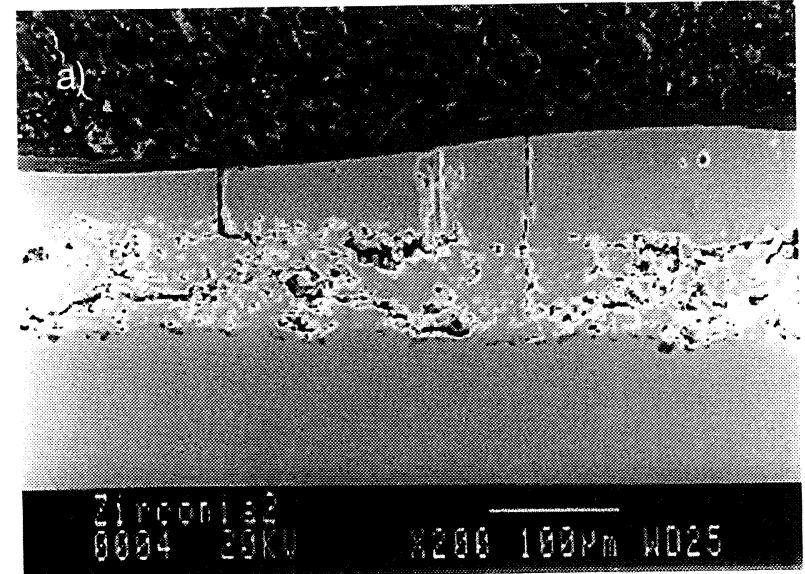

Figure 5. SEM of the transverse section of the $\mathrm{S} 2$ coating.

Figura 5. MEB de la sección transversal de la capa S2.

tests have shown similar results in terms of corrosion behaviour. It can also be observed that the three sealed coatings presented better corrosion resistances when compared with assprayed coatings.

The sealed coatings have shown a higher susceptibility to improve corrosion resistance due to absence of porosity. They exhibited a range of corrosion rates from 0.68 to $3.85 \mu \mathrm{A} / \mathrm{cm}^{2}$ and assprayed coating a range between 8.02 to $9.56 \mu \mathrm{A} / \mathrm{cm}^{2}$. In addition, the corrosion potential has shown a significant difference about

Rev. Metal. Madrid Vol. Extr. (2005) 154-159

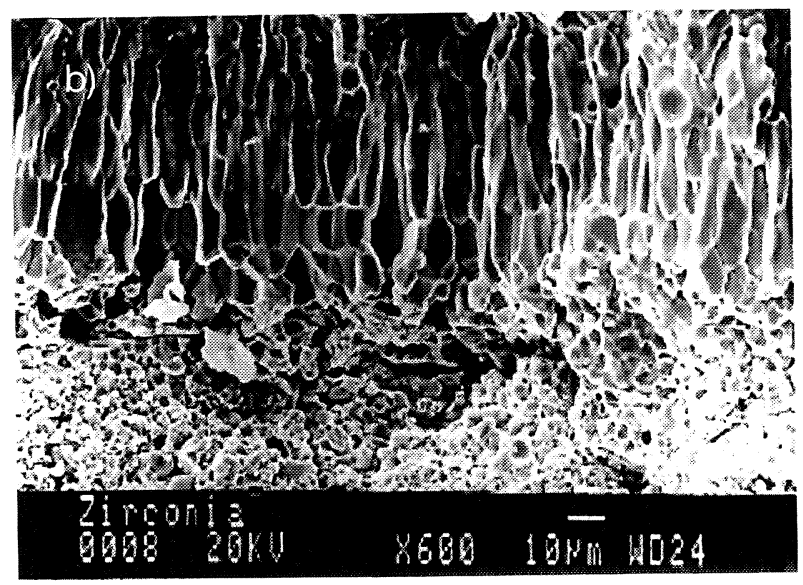

$200 \mathrm{mV}$ toward the noble side. It can also be observed in figure 6a) a difference in corrosion behaviour between the three sealed coatings. The micrographs shown in figure 4 , permit to observe a strong influence of the microstructure on the corrosion resistance. The best corrosion resistance was obtained for the S2 sealed coating, which has presented a denser and fine cellular structure. This structure has presented better results in terms of homogeneity, grain size and crack incidence than the other two sealed coatings. 


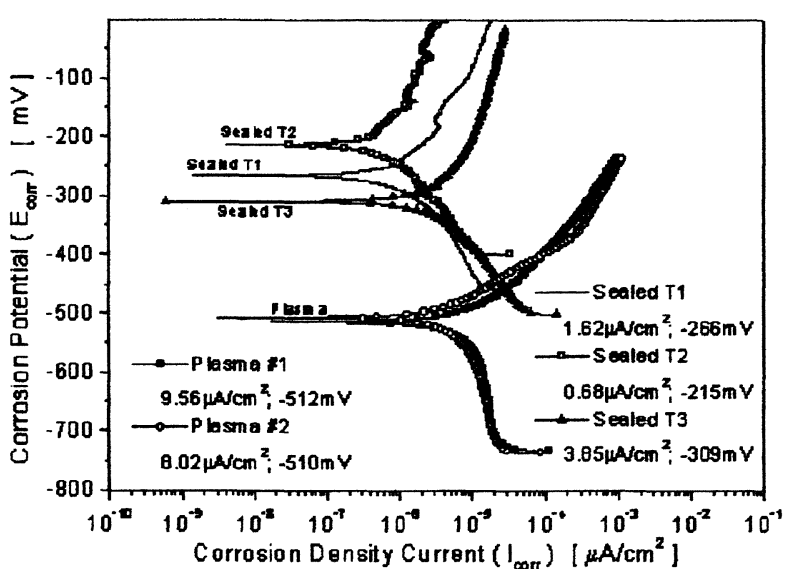

(a)

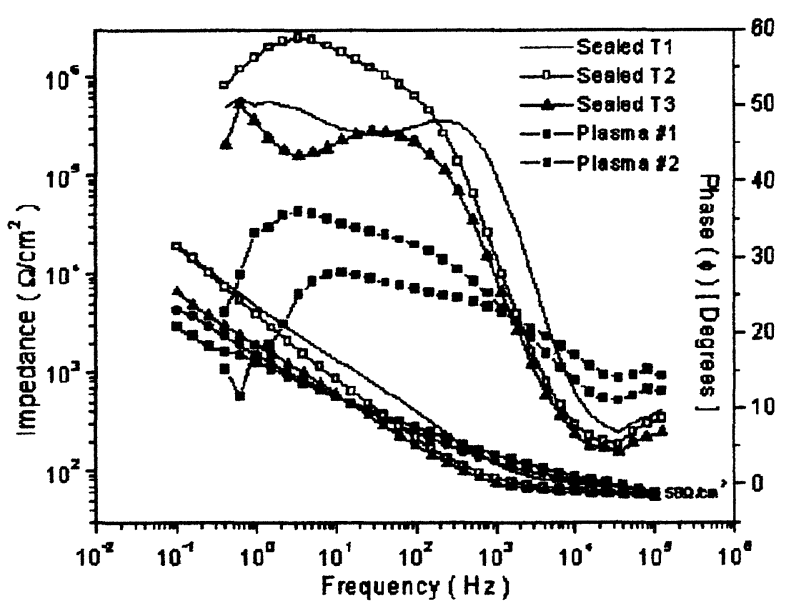

(b)

Figure 6. Polarization curves (a) and EIS diagrams (b), respectively, of the as-sprayed and as-sealed coatings in a $3 \%$ $\mathrm{NaCl}$ solution.

Figura 6. Curvas de polarización (a) y Diagramas EIS (b) de las capas de proyección por plasma y selladas por láser en una solución $\mathrm{NaCl}$ al $3 \%$.

\section{CONCLUSIONS}

Plasma sprayed $\mathrm{ZrO}_{2}$ 8wt. \% $\mathrm{Y}_{2} \mathrm{O}_{3}$ coatings have been laser sealed under different operating parameters and the characteristics of the sealed layer were analysed. The following conclusions can be drawn:

- A shiny surface layer of low roughness and fine cellular structure on the plasma sprayed zirconia coatings was produced by laser sealing process.

- The sealed layer presents a network of cracks which are perpendicular to the free surface but is free of porosity.
- The structure of the sealed layer is cellular and grows perpendicular to the free surface of the coating.

- The sealed layer consists of cubic, tetragonal and non-transformable tetragonal phases. No monoclinic phase was observed in any case experimentally examined.

- Laser sealing increases the microhardness from about $900 \mathrm{HV}$ for an as-sprayed layer to about $1700 \mathrm{HV}$ for the as-sealed layer.

- The sealed coatings have shown better corrosion resistance than the as sprayed coatings due to the absence of porosity.

- The corrosion behaviour is strongly dependent on the treatment conditions.

- Both EIS and polarisation tests have shown similarity in terms of corrosion behaviour for assprayed and as-sealed coatings performed in a 3 $\% \mathrm{NaCl}$ solution.

\section{Acknowledgements}

The authors acknowledge financial support provided by FAPESP and CNPq. The authors also would like to thank LNLS for laser processing of the samples.

\section{REFERENCES}

[1] R. Stevens, Zirconia and Zirconia Ceramics, Magnesium Elektron Ltd., $2^{\text {nd }}$ Edition, 1986, p. 51.

[2] W.E. LeE and W.M. RaINFORTH, Ceramic Microstructure, Chapman \& Hall, London, England, 1994, pp. 317-387.

[3] J.F. Bisson, D. Fournier, M. Poulain, O. Lavigne and R. Mérvel, J. Am. Ceram. Soc. 83 (2000) 1993-1998.

[4] R. Caruso, F. Pla, A.D. Parralejo and F. Guiberteau, Rev. Metal. Madrid 37 (2001) 311-315.

[5] F. Gutiérrez-MorA, M. JimÉnez-Melendo and A. Domínguez-Rodríguez, Rev. Metal. Madrid 37 (2001) 281-284.

[6] A. Gallardo, D. Gómez, J. Martínez-Fernández and A. Domínguez-Rodríguez, Rev. Metal. Madrid 37 (2001) 299-302.

[7] N. Iwamoto, N. Umesaki, Y. Katayama and H. Kuroki, Surf. Coat. Technol. 34 (1988) 59-67.

[8] A. Petitbon, D. Guignot, U. Fischer and J.M. Guillemont, Mater. Sci. Eng. A121 (1989) 545-548.

[9] C. Xin, T. Zhenyl and C. Kun, Proc. $2^{\text {nd }}$ Int. Semin. Surf. Eng. High Energy Beams, IFHT, Lisbon, Portugal, 1989, pp. 259-264.

[10] G. Gravanis, A. Tsetsekou. TH. Zambetakis, C. Stournaras and E. Hontzopoulos, Surf. Coat. Technol. 45 (1991) 245-253. 
[11] Y. He, L. Winnubst, A.J. BurggraAf, H. Verweij, P.G.Th. VAn der Varst and B. DE With, J. Am. Ceram. Soc. 80 (1997) 377-380.

[12] A. Petitbon, L. Boguet and D. Delsart, Surf. Coat. Technol. 49 (1991) 57-61.

[13] K. Mohammed-Jasim, R.D. Rawlings and D.R.F. West, J. Mat. Sci. 26 (1991) 909-916.

[14] K. Mohammed-Jasim, R.D. Rawlings and D.R.F. West, Surf. Coat. Technol. 53 (1992) 75-86.

[15] R. Sivakumar and B.L. Mordike, Surf. Eng. 4 (1988) 127-140.

[16] P.C. Tsai, H.L. TSAI and D.C. Tu, Mat. Sci. Eng. A165 (1993) 167-173.

[17] E. Ramous, Laser de Puissance et Traitements des Matériaux, A.B. Vannes (Ed.), Presses Polytechniques et Universitaires Romandes, Lausanne, Suisse, 1991, pp. 600-610.

[18] H. Caudevilla, A. Romo, J.C. Domingo, C. López, J.J. Pena and G.F. De LA Fuente, Rev. Metal. Madrid 34 (1998) 87-88.

[19] F.S. Galasso and K. Veltri, J. Am. Ceram. Soc. Bull. 62 (1988) 253-254.
[20] K. MOHAmmed-JASIM, D.R.F. WeST and W.M. StEEN, J. Mater. Sci. Lett. 7 (1988) 1307-1309.

[21] K. Mohammed-Jasim, D.R.F. WeSt, W.M. Steen and R.D. RaWLINGS, Laser Materials Processing (ICALEO'88), G.J. Bruck (Ed.), Springer-Verlag IFS (Publications) Ltd., UK, 1989, pp. 17-31.

[22] K. MOHAMmED-Jasim, R.D. RaWlingS and D.R.F. WeSt, J. Mater. Sci. 27 (1992) 1937-1946.

[23] K. MOHAmmed-Jasim, R.D. Rawlings and D.R.F. West, J. Mater. Sci. 27 (1992) 3903-3910.

[24] K. MOHAMmED-JAsim, R.D. RaWLINGS and D.R.F. West, Mater. Sci. Technol. 8 (1992) 83-91.

[25] A. ADAMSKI and R. MCPHERSON, in Advances in Thermal Spraying ITSC'86, 1986, pp. 555-562.

[26] R. A. Miller and C.C. Berndt, Thin Solid Films 119 (1984) 195-202.

[27] Z. ZaPLATYNSKY, Thin Solid Films 95 (1982) 275-284.

[28] H.L. Tsai, P.C. Tsai and D.C. TU, Mat. Sci. Eng. A161 (1993) $145-155$.

[29] J.H. SHIED and S.T. Wu, Appl. Phys. Lett. 59 (1991). 